\title{
AN INTERNATIONAL CONVENTION ON REFugee ResetTLEMENT
}

\section{MIAH GIBSON*}

Forced migration has been the subject of intense debate in the past 50 years and has spawned a wealth of literature as a result. Few commentators, however, have considered the value or viability of an international agreement on refugee resettlement that would include mandatory resettlement quotas. This article puts forward a proposal for an International Convention on Refugee Resettlement. Such a convention would, I argue, help to address some of the current limitations of resettlement as a solution to the increase in refugee numbers. Appendix 1 contains the suggested wording for such a convention, drawing on several international human rights treaties (particularly the 1951 Convention Relating to the Status of Refugees) as well as resettlement principles and policies set out by the Office of the United Nations High Commissioner for Refugees. Appendix 2 provides explanatory notes for the draft wording. It is hoped that such wording might be of use to those campaigning for the development of a binding, international agreement on resettlement.

\section{INTRODUCTION}

'The world is awash with refugees', wrote Peter Schuck, Simeon E Baldwin Professor of Law Emeritus at Yale University and a well-known commentator on refugee and migration law, in $1997 .{ }^{1}$ At that time, the United Nations High Commissioner for Refugees ('UNHCR') estimated the global refugee population to be 13 million. $^{2}$ As at 31 May 2017 it was 25.9 million - the

\footnotetext{
* JD (with Distinction), University of Southern Queensland; BA (Media and Communications), University of Melbourne; Dip Languages (Russian), Macquarie University; GradDipLegPrac, College of Law Australia; refugee and migration law practitioner and member of the European Resettlement Network.

${ }^{1}$ Peter H Schuck, 'Refugee Burden Sharing: A Modest Proposal' (1997) 22(2) Yale Journal of International Law 243, 244.

${ }^{2}$ United Nations High Commissioner for Refugees ('UNHCR'), The State of the World's Refugees: A Humanitarian Agenda (1997) <http://www.unhcr.org/3eb7bb534.html>.
} 
highest level of people displacement on record. ${ }^{3}$ The international community is struggling to provide protection and assistance to this extremely vulnerable group of people.

One of the means by which protection and assistance can be provided is through resettlement. The UNHCR defines resettlement as the selection and transfer of refugees from a state in which they have sought protection (the 'asylum country') to a third state which has agreed to admit them as refugees with permanent residence status (the 'resettlement country'). ${ }^{4}$ The status provided ensures that the refugee will not be forcibly expelled or returned to his or her country of origin ('refoulement') and will be able to access rights similar to those enjoyed by nationals of the resettlement country. Resettlement carries with it the opportunity to eventually become a naturalised citizen of the resettlement country. ${ }^{5}$

Resettlement is one of three durable solutions for refugees. The other two are voluntary repatriation, whereby the refugee returns to his or her country of origin voluntarily when it is safe to do so; ${ }^{6}$ and, local integration, whereby the refugee settles in the asylum country (with that country's permission). ${ }^{7}$ The hosting of large refugee populations can present challenges for asylum countries through increasing pressures on the asylum country's economy, causing social disruption, posing security risks, and burdening the health and welfare systems of the country concerned.

Resettlement is considered an exercise in 'burden-sharing'. It eases the pressures on asylum countries (which are typically developing countries) ${ }^{8}$ by shifting some of the resource-drain to resettlement countries (typically

${ }^{3}$ UNHCR, UNHCR Projected Global Resettlement Needs 2020 (Report from 25th Annual Tripartite Consultations on Resettlement, 1-2 July 2019) $9<$ https://www.unhcr. org/5d1384047.pdf>.

4 'Frequently Asked Questions about Resettlement', UNHCR (November 2013) <http://www. unhcr.org/524c31666.pdf>.

5 UNHCR, UNHCR Resettlement Handbook 2011 (July 2011) <http://www. refworld.org/docid/4ecb973c2.html>.

6 'Voluntary Repatriation', UNHCR (Web Page, 2017) <http://www.unhcr.org/en-au/voluntaryrepatriation-49c3646cfe.html>.

7 'Local Integration', UNHCR (Web Page, 2017) <http://www.unhcr.org/en-au/local-integration$49 \mathrm{c} 3646 \mathrm{c} 101 . \mathrm{html}>$.

${ }^{8}$ Some $86 \%$ of refugees live in the developing world. See Sarah Deardorff Miller, Assessing the Impacts of Hosting Refugees (World Refugee Council Research Paper No 4, Centre for International Governance Innovation, August 2018). 
developed countries). ${ }^{9}$ Of course, refugees also provide economic, cultural and social benefits for the countries that receive them, and resettlement countries have profited from this. ${ }^{10}$

In this article, I explain why resettlement remains an important tool in addressing current refugee crises and provide a brief outline of the resettlement process and of the history of resettlement. I also outline the problems associated with resettlement, including the lack of available places, the use of resettlement to justify harsh asylum policies, the tainting influence of domestic pressures and foreign policy on resettlement programs, and the inclusion of discriminatory criteria in resettlement decision-making.

I examine how resettlement is currently regulated and consider the potential impact of the Global Compact on Refugees (the 'Compact'), adopted by the United Nations (UN) General Assembly in 2018. ${ }^{11}$ I then propose a new multilateral convention that will address the shortcomings of resettlement as a tool for the protection of refugees: the 'International Convention on Refugee Resettlement'. I discuss the advantages and disadvantages of this proposal, and explain why the time is ripe for the international community to consider it.

Finally, I offer a suggested wording for this Convention, drawing on recent commentary about resettlement from the UNHCR.

\section{Discussion}

\section{A The Resettlement Process}

There is no legal obligation on any country, including those countries that are party to the Convention Relating to the Status of Refugees (the '1951

${ }^{9}$ Stefan Sperl and Irinel Brădişteanu, Refugee Resettlement in Developing Countries: The Experience of Benin and Burkina Faso, 1997 - 2003: An Independent Evaluation (UNHCR Evaluation and Policy Analysis Unit and Resettlement and Special Cases Section, April 2004) <https://www.unhcr.org/40cd76a8a.pdf>. The authors indicate that the Human Development Index was used to determine the definition of 'developing' as opposed to 'developed' countries: at 3 .

10 AMES and Deloitte Access Economics, Small Towns Big Returns: Economic and Social Impact of the Karen Resettlement in Nhill (Report, 2015) <https://www2.deloitte.com/ content/dam/Deloitte/au/Documents/Economics/deloitte-au-economics-small-towns-bigreturns-nhill-resettlement-270415.pdf>.

${ }^{11}$ Office of the UNHCR, Report of the United Nations High Commissioner for Refugees: Part II Global Compact on Refugees, Supplement No 12 A/73/12 (Part II) (2 August 2018, adopted 17 December 2018) ('Global Compact on Refugees'). 
Convention') ${ }^{12}$ and the Protocol Relating to the Status of Refugees (the '1967 Protocol' $),{ }^{13}$ to resettle refugees. Resettlement is an entirely voluntary activity.

The countries that choose to undertake resettlement generally enlist the help of the UNHCR to select potential candidates. The UNHCR undertakes resettlement in furtherance of its mandate to arrange international protection and durable solutions for refugees. ${ }^{14}$ The first step in the UNHCR process is the determination that the person is a refugee, known as Refugee Status Determination ('RSD'). This may be carried out by officials of the asylum country hosting the refugee or, if the country is unable or unwilling to do so, by the UNHCR. ${ }^{15}$ Under the 1951 Convention and the 1967 Protocol a refugee is defined as someone who is outside their country of origin, unable or unwilling to return or avail themselves of the protection of that country, because they have a well-founded fear of being persecuted for reasons of race, religion, nationality, membership of a particular social group, or political opinion. ${ }^{16}$

Once the person has been recognised as a refugee, they are entitled to the protections provided by the 1951 Convention and 1967 Protocol. Those who face protection risks in the asylum country or have particular needs may be considered by the UNHCR for resettlement. Only refugees who have one or more of the following categories of need can be considered for resettlement: ${ }^{17}$

1. Legal and/or physical protection needs in the asylum country, including those arising from a threat of refoulement;

2. The needs arising from the refugee being a survivor of torture and/or violence, in particular where repatriation or the conditions of asylum

\footnotetext{
${ }^{12}$ Convention Relating to the Status of Refugees, opened for signature 28 July 1951, 189 UNTS 137 (entered into force 22 April 1954) art 1.

${ }^{13}$ Protocol Relating to the Status of Refugees, signed 31 January 1967, 606 UNTS 267 (entered into force 4 October 1967) art 1.

${ }^{14}$ Statute of the Office of the United Nations High Commissioner for Refugees A/RES/428(V) (14 December 1950) art 9.

${ }^{15}$ Rachel Westerby and Sophie Ngo-Diep, Welcome to Europe! A Comprehensive Guide to Resettlement (International Catholic Migration Commission, July 2013) $10<\mathrm{http} / / / \mathrm{www}$. resettlement.eu/sites/icmc.tttp.eu/files/ICMC\%20Europe-Welcome\%20to\%20Europe.pdf>.

${ }^{16}$ Note that this definition has since been extended by the 'generalised violence' category, and by regional agreements such as the 1969 Organization of African Unity Convention Governing the Specific Aspects of Refugee Problems in Africa and the 1984 Cartagena Declaration on Refugees. However, the original definition suffices for the purposes of this article. See BC Nirmal, 'Refugees and Human Rights' [2001] 6 ISIL Year Book of International Humanitarian and Refugee Law 94, 94.

${ }^{17}$ UNHCR Resettlement Handbook 2011 (n 5) 216.
} 
could result in further traumatisation and/or a heightened risk; or where appropriate treatment is not available in the asylum country;

3. Medical needs, in particular where life-saving treatment is not available in the asylum country;

4. The special needs of women and girls at risk, who have protection problems particular to their gender;

5. The need for family reunification, when resettlement is the only means to reunite refugee family members who, owing to flight or displacement, are separated by borders or continents;

6. The special needs of children and adolescents at risk where a Best Interests Determination ${ }^{18}$ supports resettlement;

7. The special needs of those who have no foreseeable alternative durable solutions. In this case resettlement can be used strategically and/or can create possibilities for comprehensive solutions.

The assessment of resettlement need is generally done during one or more faceto-face interviews. UNHCR staff may also conduct background checks and visits to the refugee's home. The resettlement staff then complete a Resettlement Registration Form, or a similar document, which includes biographical data on the refugee and their family members, a summary of the RSD and information about the refugee's resettlement needs. ${ }^{19}$ This form is then submitted to a resettlement country for consideration.

The decision on which resettlement country should receive the refugee is based on the availability of resettlement places, the urgency of the resettlement need and the resettlement country's specific criteria. Most countries impose their

\footnotetext{
${ }^{18}$ A 'Best Interests Determination' is a formal process designed to determine a child's best interests for particularly important decisions affecting them, such as resettlement. It incorporates strict procedural safegards. See UNHCR, UNHCR Guidelines on Determining the Best Interests of the Child (Guide, May 2018) <https://www.unhcr.org/4566b16b2.pdf>.

19 UNHCR Resettlement Service, UNHCR-NGO Toolkit for Practical Cooperation on Resettlement (Policy Instructions, June 2011) <http://www.unhcr.org/en-au/protection/ resettlement/4cd418c89/unhcr-ngo-toolkit-practical-cooperation-resettlement-operationalactivities.html>.
} 
own additional resettlement criteria, such as good health, good character, family size, family composition, and so-called 'integration potential' ${ }^{20}$

Once the resettlement country has received the submission, government officials will generally interview the refugee and their family members again and may conduct further health and character checks. Some countries accept resettlement submissions on a 'dossier' basis, that is, without conducting their own interview with the refugee. The resettlement country retains the ultimate right to reject or accept the refugee for resettlement. If a refugee is rejected, the UNHCR will decide whether to refer them to an alternative resettlement country. ${ }^{21}$

\section{B A Brief History of Resettlement}

While refugee movements occurred well before the $20^{\text {th }}$ century, ${ }^{22}$ large-scale resettlement emerged in the aftermath of World War II, when many hundreds of thousands of European refugees were resettled within Europe and in countries such as Australia and the United States. ${ }^{23}$ During the Indochinese wars of the late 1970s and 1980s, approximately 1.2 million Vietnamese refugees and other asylum seekers were resettled in 30 different countries. ${ }^{24}$ At this time resettlement was seen as the preferred solution for refugees escaping this conflict. ${ }^{25}$

\footnotetext{
${ }^{20}$ Sean Henderson, 'Is “Integration Potential” a Criterion for Resettlement?' (Speech, European Council on Refugees and Exiles Biannual General Meeting, Paris, France, 30-31 October 2008) $\langle$ http://www.refworld.org/pdfid/492a7a4b2.pdf>.

${ }^{21}$ UNHCR Resettlement Service, UNHCR Guidelines on the Resubmission of Resettlement Cases (Guidance Paper, UNHCR, 2012) <http://www.refworld.org/pdfid/4ff165b12.pdf>.

${ }^{22}$ See, eg, Alyssa Girvan, '400 Years of Refugee Movement to the UK', Refugee History (Timeline Resource, June 2018) 1-3 <https://static1.squarespace.com/static/5748678dcf80a1 ffcaf26975/t/5b27e22baa4a99efbe7e7a33/1529340463491/Refugee+Timeline.pdf>; Sylvie Aprile and Delphine Diaz, 'Europe and its Political Refugees in the $19^{\text {th }}$ Century', tr Kate McNaughton, Collège de France 1530 (Essay, 18 April 2016) 1-3 <https://booksandideas.net/Europe-and-its-Political-Refugees-in-the-19th-Century.html>.

${ }^{23}$ See, eg, 'History of the U.S. Refugee Resettlement Program', Refugee Council USA (Web Page, 2017) <http://www.rcusa.org/history/>; 'How Do Refugees Come to Australia under its Refugee and Humanitarian Program?', Refugee Council of Australia (Web Page, 11 May 2016) 9-10<https://www.refugeecouncil.org.au/coming-to-australia/>.

${ }^{24}$ Sébastien Moretti, 'Southeast Asia and the Disenchantment with Resettlement' (February 2017) 54 Forced Migration Review 20; Shauna Labman, 'Resettlement's Renaissance: A Cautionary Advocacy' (2007) 24(2) Refuge 35, 36.

${ }^{25}$ John Fredriksson and Christine Mougne, Resettlement in the 1990s: A Review of Policy and Practice, UN Doc EVAL/RES/14 (December 1994) 5.
} 
Yet the magnitude of the Indochinese resettlement operation brought certain problems to the fore. While the first waves of asylum seekers had fled persecution in their home countries, and fell within the international definition of refugee, ${ }^{26}$ the later waves from the early 1980s into the early 1990s included a considerable number who had left Vietnam for economic and social reasons. ${ }^{27}$ The UNHCR found that the decision to adopt resettlement as the preferred solution ${ }^{28}$ and to take an 'across-the-board' approach to resettlement in the region had created a pull factor for many Vietnamese. ${ }^{29}$

From this point onwards, and in order to help prevent the mixing of refugee and economic migrant flows in future, the UNHCR shifted its stance, and resettlement became the solution of 'last resort'. It was only considered if voluntary repatriation and local integration were not possible. ${ }^{30}$ In 1992, the UNHCR declared the 1990s to be the 'decade of repatriation' and emphasised that the UNHCR should pursue every opportunity for voluntary repatriation. ${ }^{31}$

Resettlement numbers over this period are indicative of these trends: total global resettlement in 1970 was 1366 , but this jumped to 69,871 in $1980 .{ }^{32}$ It reached a peak of 176,635 in 1990 , before dropping significantly in the following decade. ${ }^{33}$ The fear of international terrorism that followed the

${ }^{26} \mathrm{~S}$ Chantavanich and P Rabe, 'Thailand and the Indochinese Refugees: Fifteen Years of Compromise and Uncertainty' (1990) 18(1) Southeast Asian Journal of Social Science 66, 668.

${ }^{27}$ Fredriksson and Mougne (n 25) 20, 32; Lesleyanne Hawthorne, Refugee: The Vietnamese Experience (Oxford University Press, 1982).

${ }^{28}$ This was due to the sheer volume of refugees and the international community's response, which pushed countries to offer resettlement. See eg Shamsul Bari, 'Refugee Status Determination under the Comprehensive Plan of Action (CPA): A Personal Assessment' (1992) 4(4) International Journal of Refugee Law 487; W Courtland Robinson, 'The Comprehensive Plan of Action for Indochinese Refugees, 1989-1997: Sharing the Burden and Passing the Buck' (2004) 17(3) Journal of Refugees Studies 319, 324-6.

${ }^{29}$ Moretti (n 24) 20; Justin Huynh, 'Tales of the Boat People: Comparing Refugee Resettlement in the Vietnamese and Syrian Crises' (2016) 48 Columbia Human Rights Law Review 198, 204.

${ }^{30}$ Labman (n 24) 36; Haruno Nakashiba, Postmillennial UNHCR Refugee Resettlement: New Developments and Old Challenges, (Research Paper No 265, UNHCR Policy Development and Evaluation Service, November 2013) 4.

${ }^{31}$ Sadako Ogata, UN High Commissioner for Refugees, 'Statement by Mrs Sadako Ogata' (Speech, International Management Symposium, Switzerland, 25 May 1992) <https://www.unhcr.org/en-au/admin/hcspeeches/3ae68faec/statement-mrs-sadako-ogataunited-nations-high-commissioner-refugees-international.html>.

32 'Population Statistics', UNHCR (Web Page, Database) <http://popstats.unhcr.org/en /resettlement>.

${ }^{33}$ Ibid. 
September 11 attacks on the World Trade Centre in 2001 contributed to a large reduction in refugee resettlement: it had dropped to 50,079 by $2002 .^{34}$

In 2015, even after resettlement countries pledged a massive increase in the numbers of Syrians they were prepared to resettle, the total number of refugees resettled was 107,048 - well short of its peak in $1990^{35}$ and less than $10 \%$ of the number of refugees assessed as requiring resettlement. ${ }^{36}$ Of the 1.2 million refugees assessed as needing resettlement in 2018, only 55,692 were actually resettled; in other words, less than $5 \%$ of global refugee resettlement needs were met in 2018. For 2019, it is estimated that 1.4 million refugees, residing in 65 countries of asylum, will need resettlement. ${ }^{37}$

The discrepancy between resettlement need and resettlement opportunity has led many to conclude that resettlement is simply not a viable solution for refugees. ${ }^{38}$ Based on the resettlement outcome in 2018, it would take some 20 years to resettle even the refugees currently in need of resettlement. Resettlement countries are very conservative in their resettlement programs. They are unwilling to commit to large-scale resettlement which may prove costly, a drain on infrastructure and resources, and unpopular domestically. ${ }^{39}$ Resettlement in its current incarnation is thus not an effective burden-sharing tool. $^{40}$

The imbalance between resettlement need and resettlement availability is not the only argument against resettlement. Resettlement has also been criticised because:

1. it has been used by some states to reduce their asylum obligations; ${ }^{41}$

\footnotetext{
${ }^{34}$ Ibid.

${ }^{35}$ Ibid. Note that this figure represents arrivals of resettled refugees, with or without the UNHCR's assistance. This dataset is based on Government statistics and, in principle, excludes other humanitarian admissions.

${ }^{36}$ UNHCR Projected Global Resettlement Needs 2020 (n 3).

37 'Less Than 5 Per Cent of Global Refugee Resettlement Needs Met Last Year', UNHCR (Summary of press briefing, 19 February 2019) <https://www.unhcr.org/en-au/news/briefing/ 2019/2/5c6bc9704/5-cent-global-refugee-resettlement-needs-met-year.html>.

${ }^{38}$ Oliver White, 'Why Resettlement Is Not the Solution to the World's Refugee Crisis', Jesuit Refugee Service Australia (10 October 2016) <http://www.jrs.org.au/resettlement-not-solutionworlds-refugee-crisis/>.

${ }^{39}$ Schuck (n 1) 249.

${ }^{40}$ Labman (n 24) 37.

${ }^{41}$ White (n 38).
} 
2. it is vulnerable to the forces of domestic and international politics; ${ }^{42}$ and

3. it is discriminatory because resettlement countries impose additional, non-protection-based criteria to exclude refugees, leaving them with no durable solution. ${ }^{43}$

These criticisms are considered in more detail under the next heading.

\section{Problems with Resettlement}

\section{The Trade Off with Asylum}

Resettlement is not mandatory. There is no legal obligation on a country to resettle refugees and no refugee has a right to resettlement ${ }^{44}$ Rather, a refugee's right to asylum is protected by the 1951 Convention and the 1967 Protocol. Article 33 of the 1951 Convention stipulates that no Contracting State shall refoule a refugee to the frontiers of territories where their life or freedom would be threatened on account of their race, religion, nationality, membership of a particular social group or political opinion. ${ }^{45}$

As Peter Schuck has pointed out, this is the only clear obligation contained in the 1951 Convention; most of the other provisions contain qualifying phrases and other limitations that actually protect the interests of the receiving state. ${ }^{46}$ Some have inferred a principle of international solidarity from the text of the 1951 Convention and other international instruments but, as Schuck notes, this does not equate to an authoritative legal principle and there have been very few instances of effective burden-sharing arrangements which expand refugee protection. ${ }^{47}$

\footnotetext{
42 Labman (n 24) 38-40.

${ }^{43}$ Henderson (n 20) 2-3.

44 Shauna Labman, 'Queue the Rhetoric: Refugees, Resettlement and Reform' (2011) 62 University of New Brunswick Law Journal 55, 56.

451951 Convention (n 12) art 33.

${ }^{46}$ Peter H Schuck, 'Refugee Burden Sharing: A Modest Proposal Fifteen Years Later?' in Anita Shapira et al (eds), Contemporary Challenges to the Nation State: Global and Israeli Perspectives, vol 3: The Nation State and Immigration: The Age of Multiculturalism, ch 4 (2014) 67, 73.

${ }^{47}$ Ibid.
} 
The UNHCR has been at pains to point out that resettlement and asylum should be viewed as two distinct but complementary possibilities, to be 'pursued in tandem, and not used to work against each other'. ${ }^{48}$ Yet some countries deliberately use resettlement as a means of reducing access to asylum and avoiding their non-refoulement obligation. ${ }^{49}$ Canada, for example, introduced tighter border controls in 2010 - including mandatory detention and bans on applying for permanent residency — which make it more difficult for a refugee to claim asylum, while simultaneously increasing the number of resettlement places provided to refugees. ${ }^{50}$ The larger resettlement program prevents criticism of the reduced asylum opportunities that might otherwise ensue. It also serves to separate refugees into two categories: the deserving, 'waiting patiently to come to the country' through resettlement, and the underserving who arrive in Canada 'through the back door' ${ }^{51}$ Yet, as many commentators point out, it is illogical to imply that refugees who arrive in Canada on their own to access asylum are somehow less genuine than those who are resettled through UNHCR processes, and do not require protection. ${ }^{52}$ The end result of the asylum-resettlement trade-off is that some asylum seekers are unable to access the protection they need and international legal obligations towards refugees are evaded and eroded..$^{53}$

\section{The Influence of Politics}

Numerous researchers have pointed out that decisions on the size, composition and even the existence of resettlement programs are influenced by political factors such as foreign policy and electoral interests. ${ }^{54}$ Even the UNHCR has acknowledged the 'desire of governments to facilitate the movement of certain people for foreign and domestic policy reasons' via resettlement. ${ }^{55}$

\footnotetext{
${ }^{48}$ Erika Feller, 'Address', UNHCR (Speech, International Conference on the Reception and Integration of Resettled Refugees, Norrköping, Sweden, 25 April 2001) <https://www. refworld.org/docid/429d73372.html>.

${ }^{49}$ Labman (n 44).

${ }^{50}$ Ibid 58

${ }^{51}$ Ibid, citing statements made in 2009 by the former Canadian Immigration Minister, Jason Kenney.

${ }^{52}$ Ibid 57.

${ }^{53}$ Ibid 55.

${ }^{54}$ Maria O'Sullivan, 'The Ethics of Resettlement: Australia and the Asia-Pacific Region' (2016) 20(2) International Journal of Human Rights 241; Schuck (n 46).

${ }^{55}$ UNHCR Resettlement Handbook 2011 (n 5) 47.
} 
Resettlement in the United States is illustrative. Some $40 \%$ of the US's total resettlement intake between 1959 and 1991 was from the Soviet Union. ${ }^{56}$ There were strong ideological reasons for this: refugees resettled during the Cold War helped provide justification for the US's political stance at the time. Their defection was seen as an ideological triumph. ${ }^{57}$ From a practical perspective, this large resettlement program also helped address labour shortages in the postwar economic boom. ${ }^{58}$

Indochinese resettlement in the 1970s and 1980s was motivated by a different political agenda: namely, a need to provide some form of recompense for the role the US played in the Vietnam War. ${ }^{59}$ The resettlement of Iraqis from 2007 onwards may have had a similar rationale. ${ }^{60}$ Commenting at the time on the resettlement of Iraqis, the then Senator Edward M Kennedy of Massachusetts noted, 'we can't solve the problem alone, but we obviously bear a heavy responsibility for the crisis' ${ }^{61}$ The researcher SB Ray has argued that the greatest beneficiaries of US resettlement have been refugees from countries that the US has engaged in war. ${ }^{62}$

This is not to say that those resettled from the Soviet Union, Vietnam and Iraq during these periods were not in need of resettlement. Allowing foreign policy goals and domestic interests to dictate the size and composition of resettlement programs will, however, leave a large number of refugees without access to resettlement, simply because they are from countries that are not politically influential or domestically 'popular'. Countries in Africa (described as the 'neglected continent' by the Norwegian Refugee Council due to the lack of funding for refugee protection), ${ }^{63}$ particularly sub-Saharan Africa, suffer the most. In 2018, 17,094 refugees were resettled from Africa (excluding North

\footnotetext{
${ }^{56}$ Thais Bessa, 'From Political Instrument to Protection Tool? Resettlement of Refugees and North-South Relations' (2009) 26(1) Refuge 91, 93.

${ }^{57}$ Ibid.

${ }^{58}$ Ibid.

${ }^{59}$ Shalini Bhargava Ray, 'Optimal Asylum' (2013) 46(5) Vanderbilt Journal of Transnational Law 1215,1223 .

${ }^{60}$ Ibid.

${ }^{61}$ Rachel L Swarns and Katherine Zoepf, 'More Iraqi Refugees Are Headed to U.S.', New York Times (online, 14 February 2007) <http://www.nytimes.com/2007/02/14/washington/14 refugees.html>.

${ }^{62}$ Ray (n 59).

${ }^{63}$ Richard Skretteberg, '2019 Will Be Another Year of Crises', Norwegian Refugee Council (Web Page, 2019) <https://www.nrc.no/shorthand/fr/2019-will-be-another-year-of-crises/ index.html>.
} 
Africa) ${ }^{64}$ while the total resettlement needs for this region were estimated at almost $511,000 .^{65}$ Thus just over $3 \%$ of those needing resettlement actually departed for a resettlement country. For the Asia Pacific and Europe ${ }^{66}$ regions, these figures were $10 \%$ and $40 \%$ respectively. ${ }^{67}$

The first quarter of 2017 provided perhaps the most persuasive example of the negative impact of politics on refugee resettlement. US President Trump's Executive Order 13769: Protecting the Nation from Foreign Terrorist Entry into the United States ${ }^{68}$ ('Executive Order 13769') banned the entry into the US of nationals from Iran, Iraq, Libya, Somalia, Sudan, Syria and Yemen. These are countries from which a high proportion of refugees come and were among the largest contributors of refugees to the US's resettlement program. ${ }^{69}$

Executive Order 13769 also suspended the US's refugee resettlement program for 120 days (from 16 March till 14 July 2017) for all foreign nationals. ${ }^{70}$ The total refugee resettlement program was reduced by more than half to $50,000 .^{71}$

While Executive Order 13769 was ostensibly about security, in reality it was an effort to gain support domestically for the Trump Administration. ${ }^{72}$ As outlined above, the resettlement process is lengthy and involves vetting at multiple stages, usually by both the resettlement country and the UNHCR. It is not an attractive avenue for those wishing to gain easy access to a resettlement country. A 2015 report by the Cato Institute indicated that only three of the

\footnotetext{
64 'Resettlement Data Finder', UNHCR (Web Page) <https://rsq.unhcr.org/en/\#C3ma>. Note that resettlement figures are based on departures, not numbers accepted for resettlement. Refugees accepted in one year are unlikely to depart in the same year, so the figures are indicative only.

${ }^{65}$ UNHCR, UNHCR Projected Global Resettlement Needs 2018 (Report from $23^{\text {th }}$ Annual Tripartite Consultations on Resettlement, 12-14 June 2017) 11 <https://www.unhcr.org/en$\mathrm{au} /$ protection/resettlement/593a88f27/unhcr-projected-global-resettlement-needs-2018.html >

${ }^{66}$ In UNHCR resettlement reporting 'Europe' refers to the geographical region as opposed to the political region (ie the European Union). See UNHCR Projected Global Resettlement Needs 2020 (n 3) 44-5.

${ }^{67}$ Ibid; UNHCR Resettlement Data Finder (n 64).

6882 Fed Reg 8977 (27 January 2017).

${ }^{69}$ Population Statistics (n 32). In 2015, the US resettled almost 25,000 refugees from these seven countries.

${ }^{70}$ Executive Order 13769: Protecting the Nation from Foreign Terrorist Entry into the United States 82 Fed Reg 8977, sec 5(a) (27 January 2017).

${ }^{71}$ Ibid 5(d).

72 Todd Scribner, 'You Are Not Welcome Here Anymore: Restoring Support for Refugee Resettlement in the Age of Trump' (2017) 5(2) Journal on Migration and Human Security 263; Evan Bonsall, 'Are Syrian Refugees Really a Security Risk?', Harvard Political Review (Article, 11 December 2015) <https://harvardpolitics.com/united-states/syrian-refugees-reallysecurity-risk/>.
} 
859,629 refugees who had been resettled in the United States since 2001 had been convicted of planning a terrorist attack, and none of these plans had been carried out. $^{73}$

The revised Executive Order 13780: Protecting the Nation from Foreign Terrorist Entry into the United States,${ }^{74}$ issued after several legal challenges to Executive Order $13769,{ }^{75}$ removed the outright entry ban for foreign nationals granted admission to the United States as refugees. However, it retained the overall lower resettlement quota and the suspension of travel until 14 July 2017, after which resettlement would be conditionally resumed for individual countries after the additional checking of refugees. ${ }^{76}$ Recent media reports suggest that the 2020 resettlement quota may be reduced to between 3,000 and 10,000 or even less. ${ }^{77}$ This is down from 30,000 in $2019,{ }^{78}$ and almost 85,000 in $2016 .^{79}$

The Executive Orders made by President Trump demonstrate clearly the vulnerability of resettlement to changes in international and domestic politics. Foreign policy goals, domestic politics, economic factors, the lobbying of private interest groups and the 'mood' of the domestic population drive resettlement decisions. ${ }^{80}$ Meanwhile, large numbers of refugees who cannot access effective protection in asylum countries and cannot return home are left to languish with no indication of when they will find a safe, permanent home,

\footnotetext{
${ }^{73}$ Alex Nowrasteh, 'Syrian Refugees Don't Pose a Serious Security Threat', CATO at Liberty (Report, 18 November 2015) <https://www.cato.org/blog/syrian-refugees-dont-pose-serioussecurity-threat>.

7482 Fed Ref 13780 (6 March 2017) ('Executive Order 13780’).

${ }^{75}$ See, eg, State of Hawaii v Trump, WL 1011673 (Haw Dis Ct, 2017); International Refugee Assistance Project v Trump, WL 1315538 ( $4^{\text {th }}$ Cir, 2017).

${ }^{76}$ Executive Order 13780 (n 74).

77 Ted Hesson, 'Trump Officials Pressing to Slash Refugee Admissions to Zero Next Year' Politico (Article, 18 July 2019) <https://www.politico.com/story/2019/07/18/trump-officialsrefugee-zero-1603503>.

${ }^{78}$ Ibid.

${ }^{79}$ Zuzana Cepla, 'Fact Sheet: U.S. Refugee Resettlement', National Immigration Forum (Fact Sheet, 25 January 2019) <https://immigrationforum.org/article/fact-sheet-u-s-refugeeresettlement/>.

${ }^{80}$ Joanne van Selm, 'Refugee Protection Policies and Security Issues' in Edward Newman and Joanne van Selm (eds), Refugees and Forced Displacement: International Security, Human Vulnerability, and the State (United Nations University Press, 2003) 66, 69; Matthew J Gibney, The Ethics and Politics of Asylum: Liberal Democracy and the Response to Refugees (Cambridge University Press, 2004) 195; Elona Bokshi, 'Refugee Resettlement in the EU: The Capacity To Do It Better and To Do It More' (Research Report 2013/04, European University Institute, Robert Schuman Centre for Advanced Studies, 2013) $14<\mathrm{https} / / / w w w . e c r e . o r g / w p-$ content/uploads/2016/03/00013_20140108160733_knowresetrr-2013-04.pdf>.
} 
because their resettlement is not in accordance with a resettlement country's foreign or domestic policy goals. ${ }^{81}$

\section{$3 \quad$ Additional Criteria}

As outlined above, the UNHCR's decision on whether to refer a refugee for resettlement is based on whether the refugee demonstrates a particular vulnerability or need for protection, making their continued stay in an asylum country untenable. Yet, the decision by a resettlement country on whether or not to accept an individual refugee is not purely needs-based. Resettlement countries apply their own additional resettlement criteria, unrelated to protection needs, to exclude some individuals from resettlement even though such individuals may need it most.

One of the most commonly applied additional resettlement criteria is 'integration potential' ${ }^{82}$ Yet, exactly what constitutes 'integration potential' and how it is measured are rarely articulated ${ }^{83}$ and this can have a discriminatory impact on refugees. In some cases, refugees are held to have low integration potential if they are illiterate, have no formal education, or are unemployed. It is assumed that they will find it more difficult to obtain employment and make connections in the resettlement country and therefore will have trouble integrating. ${ }^{84}$

A lack of language skills and formal education may make resettlement more challenging initially, but such factors may be beyond the control of the refugee. ${ }^{85}$ Disruption to education and employment is almost inevitable when a refugee is forced to flee their home country, yet these circumstances may exclude them from resettlement. ${ }^{86}$

The UNHCR has expressed serious concerns about applying this 'ill-defined notion of integration potential' to resettlement, believing that it will put at risk the very foundation upon which the UNHCR's global resettlement activities are built. ${ }^{87}$ In the words of one of the UNHCR's Senior Resettlement Officers, 'the integration of refugees in a country of resettlement is a process not a criterion' ${ }^{88}$

\footnotetext{
${ }^{81}$ White (n 38).

${ }^{82}$ See, eg, Henderson (n 20); Labman (n 24).

${ }^{83}$ Henderson (n 20).

${ }^{84}$ Ibid.

${ }^{85}$ Ibid.

${ }^{86}$ Ibid.

${ }^{87} \mathrm{Ibid}$.

${ }^{88}$ Ibid (emphasis in original).
} 
and the resettlement country plays a key role in ensuring integration is successful. Yet resettlement countries continue to use integration potential as a reason to reject refugees for resettlement.

Other additional criteria imposed by resettlement countries are age, gender, family size and even nationality and ethnicity. Such criteria are usually not expressed in legislation or formal policies and are rarely announced publicly, but have a considerable impact on resettlement. ${ }^{89}$ The infiltration of discriminatory criteria into resettlement undermines the core humanitarian and non-discriminatory principles of refugee protection. ${ }^{90}$

\section{The Value of Resettlement}

Given the vast discrepancy between resettlement need and resettlement places, the use of resettlement to justify restrictive asylum policies, the influence on resettlement of foreign and domestic policy concerns, and the discrimination in resettlement decision-making, it is natural to question the continued value and viability of resettlement in its current form.

Yet, as stated in the closing comments of the NGO Annual Tripartite Consultations on Resettlement in 2009, 'Resettlement Matters!'91 Firstly, resettlement matters to the refugees who need it, and there are increasing numbers of them as voluntary repatriation becomes untenable due to the protracted nature of some civil conflicts (for example, the war in Syria). It also matters to asylum countries which still see resettlement as a respite from the burden of refugee-hosting, and a means of preventing further internal and external refugee movements which are destabilising to the asylum countries and the refugees.

In addition, resettlement matters to other refugees who may benefit from the additional 'protection space' that resettlement can open up. ${ }^{92}$ The use of resettlement to create this additional space is referred to as the "strategic use of resettlement', and involves using resettlement in a manner that maximises the

\footnotetext{
${ }^{89}$ Ibid.

${ }^{90}$ Ibid.

${ }^{91}$ Erika Feller, 'Towards the Common EU Resettlement Scheme: The Road Ahead' (Speech, Churches' Commission for Migrants in Europe Conference, Stockholm, Sweden, 25-28 August 2009) <http://www.unhcr.org/4a964cb29.pdf >

${ }^{92}$ Ibid. The term 'protection space' refers to an environment conducive to facilitating protection services by the UNHCR. See Anne Evans Barnes, 'Realizing Protection Space for Iraqi Refugees: UNHCR in Syria, Jordan and Lebanon', (Research paper No 167, UNHCR, January 2009) 1 〈https://www.unhcr.org/4981d3ab2.pdf>.
} 
direct or indirect benefits to populations other than the resettled refugees themselves, as well as the hosting state, other states or the international protection regime in general. ${ }^{93}$

Finally, resettlement matters to communities in resettlement countries, ${ }^{94}$ who have generally welcomed refugees with open arms, notwithstanding the political climate in their countries. Resettlement countries affirmed the value of resettlement at a landmark conference in September 2016, stating that resettlement 'has benefits for countries that host large refugee populations and for third countries that receive refugees'. ${ }^{95}$ While resettlement incurs costs for resettlement countries (explored further in the next section) refugees also bring skills and international connections, increase consumption and can stimulate trade and investment. ${ }^{96}$

To realise the full potential of resettlement, however, the world needs a formal agreement that commits countries to the non-discriminatory resettlement of refugees who cannot return home and cannot remain in an asylum country.

\section{E Resettlement Numbers and Current Regulation}

There is currently no global agreement that imposes a legal obligation on parties to resettle refugees. ${ }^{97}$ As outlined above, resettlement is entirely a voluntary and discretionary activity by states. ${ }^{98}$ In 2018, only 27 countries accepted refugees for resettlement. ${ }^{99}$

93 Joanne van Selm, 'Great Expectations: A Review of the Strategic Use of Resettlement' (Evaluation Report, August 2013) UNHCR 1 <https://www.refworld.org/docid/520 a407d4.html> quoting UNHCR, The Strategic Use of Resettlement (Discussion Paper Prepared by the Working Group on Resettlement, EC/53/SC/CRP.10/Add.1, 3 June 2003) <http://www.unhcr.org/refworld/docid/41597a824.html>. See also Feller (n 91) 1, 4; Nakashiba (n 30) 10-11.

${ }^{94}$ Feller (n 91) 1.

${ }^{95}$ New York Declaration for Refugees and Migrants, GA Res 71/1, UN Doc A/RES/71/1 (3 October 2016, adopted 19 September 2016) para 77 ('New York Declaration').

96 David Khoudour and Lisa Anderson, Assessing the Contribution of Refugees to the Development of Their Host Countries (Paper prepared for the Organisation for Economic Cooperation and Development Centre's Policy Dialogue on Migration and Development DEV/DOC(2017)1, 28 September 2017).

${ }^{97}$ Labman (n 44).

${ }^{98}$ O’Sullivan (n 54) 243.

99 'Information on UNHCR Resettlement', UNHCR (Web Page) <https://www.unhcr.org/en$\mathrm{au} /$ information-on-unhcr-resettlement.html> . 
In 2018 a total of 58 countries in the world were classified by the United Nations Development Program as having 'very high human development'. ${ }^{100}$ I would argue that such countries are certainly capable of resettling refugees. Many of these countries already undertake resettlement but have been shown to have the economic capacity to increase their quotas. ${ }^{101}$

Countries that offer resettlement usually have a domestic legislative regime in place to govern it. The scope of this article does not allow for a detailed analysis of each of these legislative regimes, although the UNHCR's Resettlement Country Chapters contain a useful summary of the domestic laws on resettlement in 22 resettlement countries. ${ }^{102}$ By way of summary, domestic resettlement quotas are generally set out in policies, official statements, government decisions or disallowable legislative instruments. ${ }^{103}$ This means that they can be quickly and easily amended depending on the priorities of the government or legislature. Domestic resettlement criteria often include 'national interest' ${ }^{104}$ and foreign/regional policy criteria as well as integration or 'establishment' potential. ${ }^{105}$

${ }^{100}$ United Nations Development Program, Human Development Indices and Indicators: 2018 Statistical Update (Report, 2018) <http://hdr.undp.org/sites/default/files/2018_human_ development_statistical_update.pdf >. The World Bank is no longer using the term 'developing country': Tim Fernholz, 'The World Bank is Eliminating the Term "Developing Country" from its Data Vocabulary', Quartz (16 May 2017) <https://qz.com/685626/the-world-bank-iseliminating-the-term-developing-country-from-its-data-vocabulary/>. However I have used it in this article because it is a commonly understood term and still used in UN discourse.

${ }^{101}$ Council of Europe, Committee on Migration, Refugees and Displaced Persons, 'Resettlement of Refugees, towards Greater Solidarity' (Report Doc 13001, Ref 3894, Council of Europe Parliamentary Assembly, 1 October 2012) <http://website-pace.net/ documents/19863/168397/20140313-RefugeeResettlement-EN.pdf/feccb533-f15a-49fd-b6cd0aeba5e7dee2>. This report was published in 2012, and resettlement efforts have been increased since then, but still lag well behind Europe's resettlement capacity. For the US resettlement capacity, see Katy Long, 'Why America Could - and Should - Admit More Syrian Refugees', Century Foundation (16 December 2015) <https://tcf.org/content/report/why-america-could-and-should-admit-more-syrian-refugees/>.

102 'UNHCR Resettlement Handbook and Country Chapters', UNHCR (Web Page, April 2018) $<$ http://www.unhcr.org/en-au/protection/resettlement/4a2ccf4c6/unhcr-resettlementhandbook-country-chapters.html>. There are also additional summaries compiled by the Rights in Exile Programme of the International Refugee Rights Initiative: <http://www.refugeelegal aidinformation.org/>.

${ }^{103}$ See, eg, s 207(a)(2) of the United States' Immigration and Nationality Act 1965, Pub L 89236, 79 Stat 911 which provides that the resettlement quota shall be 'such number as the President determines, before the beginning of the fiscal year and after appropriate consultation, is justified by humanitarian concerns or is otherwise in the national interest'.

${ }^{104}$ Immigration and Nationality Act 1965, Pub L 89-236, 79 Stat 911, s 207(e).

105 See, eg, Canada's Immigration and Refugee Protection Regulations SOR 2002, 227, s $139(1)(\mathrm{g})$. Note that this does not apply to refugees being resettled in Quebec. 
There are several multilateral agreements and non-binding declarations on resettlement. ${ }^{106}$ One of the newest is the Global Compact on Refugees which was adopted on 17 December 2018 by the United Nations General Assembly, ${ }^{107}$ with 181 countries voting for its adoption, three abstaining (Eritrea, the Dominican Republic and Libya), and two voting against it (Hungary and the United States).

The objectives of the Compact are to:

1. ease pressures on host countries;

2. enhance refugee self-reliance;

3. expand access to third country solutions; and

4. support conditions in countries of origin for return in safety and dignity.

The Compact contains a lot of practical guidance on how to achieve these aims, but it suffers from the same shortcomings as the other multilateral agreements and frameworks. It contains no firm, intergovernmentally-agreed outcome on the resettlement of refugees. It is intended to be operationalised through 'voluntary contributions to achieve collective outcomes and progress towards its objectives' ${ }^{108}$ The Compact states that its success relies on 'robust and wellfunctioning arrangements for burden- and responsibility-sharing', and a 'commitment on the part of the international community as a whole to providing concrete contributions' ${ }^{109}$ Yet, as discussed earlier in this article, when states are left to determine their own resettlement contributions, the number of places falls well short of need.

The Compact also does not stipulate that resettlement decisions should be made based on the needs of refugees, without reference to individual resettlement country criteria such as 'integration potential'. In fact, it states that the contributions will be determined by the relevant state taking into account its

\footnotetext{
106 Anja Radjenovic, 'Resettlement of Refugees: EU Framework', European Parliament (Legislation in Progress Briefing, April 2017) <http://www.europarl.europa.eu/ RegData/etudes/BRIE/2016/589859/EPRS_BRI(2016)589859_EN.pdf>.

${ }^{107}$ Global Compact on Refugees (n 11) 1[4].

${ }^{108}$ Ibid 3.3 [49].

${ }^{109}$ Ibid.
} 
'national realities, capacities and levels of development, and respecting national policies and priorities'. ${ }^{110}$

The lack of concrete resettlement quotas and the absence of a commitment to the use of non-discriminatory criteria in resettlement decision-making means that the Compact will unfortunately not address the main shortcomings of resettlement discussed above. This is unsurprising. A compact does not commit an agreeing party to specific remedial action. By contrast, conventions and treaties ${ }^{111}$ are legally binding on states under international law ${ }^{112}$ once they have been ratified, accepted, approved, or acceded to by a state. ${ }^{113}$

I therefore propose an International Convention on Refugee Resettlement, which will include mandatory resettlement quotas for countries with very high human development. It will also prescribe a non-discriminatory approach to resettlement decision-making, excluding the use of criteria such as 'integration potential'. In so doing, it will help insulate resettlement from foreign and domestic political pressures. An International Convention on Refugee Resettlement will also: 1) elevate resettlement as a protection instrument by giving it the status afforded to asylum; 2) ensure that asylum responsibilities are separated from resettlement responsibilities; and 3) prevent the use of resettlement as a trade-off against the provision of asylum.

Previous commentators have recognised the value of imposing quotas on states to commit them to providing protection, including resettlement. In 1997, Peter Schuck proposed the assigning of a refugee protection quota to each state, but also provided an 'out' clause whereby participating states could trade their quotas by paying other states to fulfil their obligations. This proposal has, however, been criticised by some who believe that it commodifies human

\footnotetext{
110 Ibid 3.3 [50].

111 The terms 'treaty' and 'convention' are used interchangeably here because they have the same legal effect. See eg, 'What is a Treaty?', Australian Government, Department of Foreign Affairs and Trade (Web Page) <https://dfat.gov.au/international-relations/treaties/treaty-makingprocess/Pages/treaty-making-process.aspx>.

112 Daniel Bodansky, 'Legally Binding versus Non-Legally Binding Instruments' in Scott Barrett Carlo Carraro and Jaime de Melo (eds), Towards a Workable and Effective Climate Regime (VoxEU eBook, 2015) 155, 156; Vienna Convention on the Law of Treaties, opened for signature 23 May 1969, 1155 UNTS 331 (entered into force 27 January 1980) art 2(a).

113 United Nations, Office of Legal Affairs, Treaty Section, Treaty Handbook (Guidance document, 2012) ('Treaty Handbook') pt 3.3.33. The fourth way that a treaty or convention may become binding is through definitive signature but this is rarely used for multilateral treaties and is therefore outside the scope of this article.
} 
relationships and obligations. ${ }^{114}$ In addition, such an arrangement would not address the other problems with resettlement identified in this article: it would do nothing to prevent the influence of domestic politics on resettlement, or to prevent the application of discriminatory criteria to resettlement. Schuck's proposal allows states to define the classes of refugees who could look to them for protection; they could, for example, limit protection to refugees from regions or from countries with historical ties to the state in question.

\section{F Justification for a Convention}

Treaties and conventions bind the actions of a state party not just because of formal ratification, acceptance or approval but also because:

1. they give rise to an internal sense of legal obligation and, therefore, exert a greater 'compliance pull' than a mere domestic political commitment;

2. they encourage states to judge non-compliance by other states harshly, and as a result states risk greater costs to their reputation and relations with other states if they violate the provisions;

3. they have greater effects on domestic politics than political agreements, as they influence bureaucratic routines and assist in mobilising and empowering domestic advocates; and

4. they create legal obligations that can be applied by courts, whether in an international tribunal or a state's domestic courts. ${ }^{15}$

States can, of course, limit their obligations under a convention by entering reservations. ${ }^{116}$ While reservations may weaken the legal effect of a convention, they are nevertheless useful because they broaden the pool of potential states parties. ${ }^{117}$ My draft convention, therefore, has provision for states to enter reservations, but not in relation to resettlement quotas or the non-discrimination requirements, as this would undermine the purpose of the convention and fail to address the current shortcomings of resettlement.

\footnotetext{
${ }^{114}$ Michael J Sandel, What Money Can't Buy: The Moral Limits of Markets (Farrar, Straus \& Giroux, 2013).

115 Bodansky (n 112) 161.

${ }^{116}$ Treaty Handbook (n 113) pt 3.5.

${ }^{117}$ Ibid.
} 
Conventions have several other advantages in addition to the legal obligations they impose. First, being global in nature they have a much longer reach than domestic or bilateral agreements. ${ }^{118}$ Second, they are more transparent because they can involve independent international organisations, particularly in compliance monitoring. ${ }^{119}$ For this reason, my draft Convention gives the UNHCR responsibility for overseeing its implementation and monitoring compliance, and obliges states parties to provide regular reports on their resettlement activities. Third, conventions serve a public awareness function by raising the profile of an issue of international importance. ${ }^{120}$ In this case, an International Convention on Refugee Resettlement would help communities in resettlement countries better understand resettlement and provide support to newly resettled refugees, thereby improving integration outcomes.

\section{G The Drawbacks of a Convention}

The main advantage of an International Convention on Refugee Resettlement - the fact that it can be binding under international law — is also a potential barrier to its success. A convention that forces states parties to commit to a resettlement quota and limits their ability to be selective about whom they resettle, is likely to be politically unattractive. ${ }^{121}$ The European Union's failure to impose resettlement quotas on its Member States is telling in this respect, ${ }^{122}$ as is the absence of firm resettlement commitments in the final draft of the Compact. ${ }^{123}$ After all, being able to pick and choose who becomes part of a nation and who enjoys the associated rights is an essential component of sovereign power. ${ }^{124}$ Some states may perceive mandatory resettlement quotas

\footnotetext{
${ }^{118}$ Senator Gareth Evans, Minister for Foreign Affairs, 'International Treaties: Their Impact on Australia (Speech, International Treaties Conference, Canberra, 4 September 1995) <http://australianpolitics.com/1995/09/04/international-treaties-their-impact-onaustralia.html>.

${ }^{119}$ Bodansky (n 112) 162.

${ }^{120}$ Office of the United Nations High Commissioner for Human Rights, Working with the United Nations Human Rights Programme: A Handbook for Civil Society, ch IV 'Human Rights Treaty Bodies' (2017) <http://www.ohchr.org/Documents/Publications/NgoHandbook/ngohandbook 4.pdf>.

${ }^{121}$ Schuck (n 1) 249.

122 Lyra Jakuleviciene and Mantas Bileisis, 'EU Refugee Resettlement: Key Challenges of Expanding the Practice into New Member States' (2016) 9(1) Baltic Journal of Law and Politics 93, 103.

${ }^{123}$ New York Declaration (n 95).

124 Tally Kritzman-Amir, 'International Migration Law in the Current Legal and Practical Reality: Review of Research Handbook on International Law and Migration' (2016) 49(1) Israel Law Review 131, 132-3.
} 
and non-discriminatory selection criteria as an impermissible interference with this element of sovereignty.

In addition, it could be argued that it is natural, perhaps even prudent, for political considerations to be factored into resettlement decisions and for a state to seek to assert its own interests in any arrangement with another state, even when the primary purpose is supposed to be the protection of vulnerable people. This has certainly been a feature of international aid funding over the years. ${ }^{125}$

Yet, being party to a convention is in itself an exercise and an affirmation of a country's sovereignty, a point that is often forgotten in discussions about the implications of convention ratification. ${ }^{126}$ The extensive ratification of the 1951 Convention and the 1967 Protocol $^{127}$ show us, too, that states are willing to accept limitations to sovereignty in the interests of protecting the world's most vulnerable. The non-refoulement principle is so widely understood and respected that it is now considered a principle of international customary law, applicable even to states which are not parties to the 1951 Convention. ${ }^{128}$

The ongoing relevance and influence of the 1951 Convention and the 1967 Protocol were demonstrated recently in the New York Declaration, in which the 193 Member States reaffirmed their commitment to both documents and recognised 'the importance of their full and effective application by states parties and the values they embody'. ${ }^{129}$ If states are willing to continue to accept limitations on their sovereignty in the form of non-refoulement of asylum seekers, it seems plausible that they might also accept a limitation that involves mandated, non-discriminatory refugee resettlement. In addition, the fact that they have agreed in the New York Declaration to at least consider committing to higher resettlement quotas and a non-discriminatory approach, provides some grounds for optimism.

Another argument that could be raised against a convention with mandatory resettlement quotas is the cost. States are obliged to be cautious about how they spend taxpayer money and resettlement does not come cheap. The cost of

\footnotetext{
${ }^{125}$ See, eg, Mario Novelli and Susan Robertson, 'The Politicization of Development Aid to Education after September 11' in Kenneth J Saltman (ed), Schooling and the Politics of Disaster (Routledge, 2007) ch 14.

${ }^{126}$ Evans (n 119).

127 'States Parties to the 1951 Convention relating to the Status of Refugees and the 1967 Protocol', UNHCR (Web Page, 2015) <http://www.unhcr.org/protect/PROTECTION/ 3b73b0d63.pdf>.

${ }^{128}$ Evans (n 118).

${ }^{129}$ New York Declaration (n 95) para 65.
} 
resettling a refugee in the United States in 2016 was reported to be approximately AUD 25,000, while the cost in the United Kingdom was as high as AUD $152,000 .^{130}$

Yet research shows that the resettlement of refugees is not simply a drain on financial resources; rather, it is an investment. ${ }^{131}$ Australian studies have demonstrated that the net economic impact of refugee resettlement is positive, although admittedly it may take some years for this to eventuate as refugees settle in, learn the national language, upgrade their skills and make the connections needed to find employment. ${ }^{132}$ No studies have demonstrated that resettled refugees impose an economic burden over the long term. ${ }^{133}$

The advantages of an International Convention on Refugee Resettlement outweigh the disadvantages.

\section{CONCLUSION}

The momentum is building for a global agreement on refugee resettlement. It is desperately needed, primarily to bring resettlement places into line with resettlement needs, but also to remove discriminatory criteria such as 'integration potential' from resettlement decision-making and to return resettlement to a needs-based protection solution uncorrupted by foreign policy or domestic influences and working in tandem with asylum protections.

An International Convention on Refugee Resettlement provides an ideal solution. It imposes legal obligations on states with regard to resettlement, but

\footnotetext{
${ }^{130}$ Patrick Kingsley, 'Why does Resettling a Refugee Cost $£ 17,000$ in the US — but $£ 85,000$ in Britain?' The Guardian (online), (13 September 2016) <https://www.theguardian.com/world/ shortcuts/2016/sep/13/why-does-resettling-a-refugee-cost-17000-in-the-us-but-85000-inbritain>. Note that this is a crude measure of the actual cost. The article indicates that the author simply took the cost of the total resettlement program (or the budget of the agency set up to administer refugee resettlement) and divided it by the number of refugees resettled. The conversion from British pounds to AUD was done via currency exchange website <www.xe. com> on 18 August 2019.

${ }^{131}$ This is demonstrated by the AMES and Deloitte Access Economic Report on the resettlement of refugees from Myanmar to Nhill, Australia. See AMES and Deloitte Access Economics (n 10). See also Daniel Pryor, 'How Much Do Refugees Cost the Tax Payer?', Adam Smith Institute (Article, 16 August 2017) <https://www.adamsmith.org/blog/how-much-do-refugeescost-the-taxpayer>.

132 AMES and Deloitte Access Economics (n 10). See also Richard Parsons, 'Refugees: Economic Burden or Opportunity?', E-International Relations (Article, 7 March 2016) <http://www.e-ir.info/2016/03/07/refugees-economic-burden-or-opportunity/>.

${ }^{133}$ Ibid.
} 
also offers increased transparency about resettlement. Larger resettlement programs would ease the burden on asylum countries, and potentially create conditions for the safe integration of remaining refugee populations. A convention is also more likely to bring the number of resettlement places into line with global resettlement needs than the non-binding Compact.

This article and the accompanying draft convention offer suggested wording that might be useful in building on the Compact to create a binding agreement on resettlement. 


\section{APPEndiX 1: The Convention}

\section{INTERNATIONAL CONVENTION ON REFUGEE RESETTLEMENT}

\section{PREAMBLE}

\section{THE HIGH CONTRACTING PARTIES,}

CONSIDERING that the United Nations and the international community have manifested profound concern for refugees and endeavoured to assure refugees the widest possible exercise of their fundamental rights and freedoms as enshrined in the 1951 Convention Relating to the Status of Refugees and the 1967 Protocol Relating to the Status of Refugees

CONSIDERING that states have indicated their willingness to work cooperatively at an international level to assist refugees, including through adoption of the New York Declaration for Refugees and Migrants and the Global Compact on Refugees,

CONSIDERING that it is desirable to extend the scope of protection afforded refugees by means of new international agreements,

CONSIDERING that it is necessary to find durable solutions to address refugee movements, and resettlement presents the most desirable solution for some refugees,

CONSIDERING that refugee movements create challenges for countries of first asylum, and international cooperation is required to assist them to respond,

EXPRESSING the wish that all states, recognising the social and humanitarian nature of the problem of refugees, will do everything within their power to:

protect refugees,

offer resettlement to refugees for whom there is no other durable solution,

assist each other to establish and implement resettlement in their respective states and,

prevent resettlement from becoming a cause of tension between states, 
NOTING that the Office of the United Nations High Commissioner for Refugees is charged with the task of supervising international conventions providing for the protection of refugees, and recognising that the effective coordination of measures taken to deal with this problem will depend upon the cooperation of states with the High Commissioner,

HAVE AGREED as follows:

\section{ChaPter 1: General Provisions}

\section{Article 1-Definitions}

1. Definition of the term 'resettlement'

For the purposes of the present Convention, the term 'resettlement' shall refer to the process by which a refugee is:

assessed by the UNHCR as being a refugee in need of resettlement;

referred by the UNHCR for resettlement consideration; and

selected and transferred from a state in which the refugee has sought protection to a third state that has agreed to admit the refugee as a permanent resident.

2. Definition of 'family member' of a refugee

For the purposes of the present Convention, the term 'family member' shall refer to all those who consider themselves and are considered by each other, to be part of a family, and who wish to live together.

\section{Definition of the UNHCR}

For the purposes of the present Convention, the acronym 'UNHCR' shall refer to the Office of the United Nations High Commissioner for Refugees or any other agency of the United Nations which may succeed it.

\section{Article 2 - Entry into Force}

This Convention shall come into force on the ninetieth day following the day of deposit of the third instrument of ratification or accession. 
For each state ratifying or acceding to the Convention after the deposit of the third instrument of ratification or accession, the Convention shall enter into force one year following the date of deposit by such state of its instrument of ratification or accession.

\section{Article 3 - Non-Discrimination}

Contracting States shall apply the provisions of this Convention to refugees without discrimination based on race, age, religion, ethnicity, nationality, political opinion, gender, sexual preference, disability or integration prospects. They shall apply these provisions when making any decision on whether or not to resettle a refugee.

\section{Article 4-Rights Granted apart from This Convention}

Nothing in this Convention shall be deemed to impair any rights and benefits granted by a Contracting State to refugees under any instrument or law.

\section{Article 5 - Refugee Involvement in Resettlement}

Contracting States shall, to the greatest extent possible, incorporate the views of refugees in the design and implementation of resettlement processes and services.

Contracting States shall, to the greatest extent possible, ensure that resettlement is implemented in a manner that does not reinforce the oppression of women, children and minority groups.

\section{Article 6-Resettlement Quotas}

Each Contracting State's resettlement quota shall be determined by the UNHCR annually, based on the country's resettlement capacity. The resettlement quota may be modified in the event of a natural disaster, civil conflict or other extreme event.

Contracting States which have met their annual resettlement quota shall not be compelled to accept further refugees for resettlement in the same year, but may do so if they choose.

Contracting States may, in cooperation with the UNHCR, substitute multiannual resettlement quotas for annual resettlement quotas. 


\section{Article 7 - Bilateral, Multilateral and Regional Resettlement Coordination}

Nothing in this Convention should be taken as limiting the entitlement of Contracting States to coordinate resettlement with each other, including by reallocating resettlement places among each other, on a bilateral, multilateral or regional basis, in coordination with the UNHCR.

\section{Article 8-Resettlement Transfers}

Refugees requiring resettlement who are within the territory of a Contracting State that has met its annual resettlement quota may be transferred by the Contracting State (the 'transferring state') to an alternative state (the 'receiving state'), provided that the receiving state is a party to the 1951 Convention Relating to the Status of Refugees and the 1967 Protocol Relating to the Status of Refugees.

The UNHCR is the agency responsible for identifying the receiving state, and negotiating and coordinating the resettlement transfer in cooperation with the transferring and receiving states.

The transferred refugees, once resettled, shall constitute part of the receiving state's existing annual resettlement quota (if it has one).

The resettlement transfer process shall be conducted as expediently as possible and with every effort to minimise negative impacts for the refugee and the refugee's family members.

A resettlement transfer shall not be undertaken without the consent of the refugee.

\section{CHAPTER 2: RIGHTS AND WELFARE}

\section{Article 9-Privacy}

Contracting States shall ensure that in all actions concerning the resettlement of a refugee, the privacy and personal information of the refugee are protected. 


\section{Article 10 - No Compulsion or Cost for Resettlement}

Contracting States shall not compel a refugee to resettle against his or her will, nor penalise the refugee for a decision not to resettle.

Contracting States shall not impose a monetary fee on a refugee in relation to the resettlement process.

\section{Article 11 - No Right to Resettlement}

A refugee does not have a right to resettlement.

\section{Article 12 - Determination of Resettlement Need}

The UNHCR shall be responsible for determining the total number and geographic distribution of refugees in need of resettlement and shall provide this information to Contracting States at least annually.

The UNHCR shall be responsible for determining whether an individual refugee is in need of resettlement and, if so, for referring the refugee to a state for resettlement consideration.

The decision regarding resettlement need shall be based entirely on an assessment of the protection needs of the individual and, where relevant, the individual's family members.

A decision by the UNHCR on resettlement need is not appealable.

\section{Article 13 - Resettlement Decision}

Contracting States shall decide whether or not a refugee referred for resettlement shall be resettled within their territory.

All resettlement decisions shall be non-discriminatory and a decision to deny resettlement to a refugee should be made only when compelling reasons of national security require it.

\section{Article 14 - Special Resettlement Cases}

Contracting States shall allocate at least $10 \%$ of their resettlement quota to emergency cases (or less if the emergency case pipeline has been exhausted) in cooperation with the UNHCR. 


\section{Article 15 - Integration}

Contracting States shall facilitate the efficient integration of resettled refugees, including by establishing legislative and policy instruments ensuring resettled refugees have status and rights and providing access to essential services.

\section{ChAPTER 3: EXECUTORY AND TRANSITORY PROVISIONS}

Article 16-Cooperation of the National Authorities with the United Nations

Contracting States undertake to cooperate with the UNHCR in the exercise of its functions, including the supervision of the application of this Convention.

In order to enable the UNHCR to make reports to the competent organs of the United Nations, the Contracting States undertake to provide to the UNHCR, in the appropriate form, information and statistical data requested by it concerning:

the number of resettlement places offered to refugees and the number of refugees successfully resettled by the Contracting State;

the reasons for the rejection of resettlement referrals;

the integration program/s available to resettled refugees in the Contracting State's territory;

the implementation of other articles of this Convention; and laws, regulations and decrees which are, or may hereafter be in force in the Contracting State relating to refugee resettlement.

\section{CHAPTER 4: FINAL CLAUSES}

\section{Article 17 - Settlement of Disputes}

Any dispute between parties to this Convention relating to its interpretation or application which cannot be settled by other means shall be referred to the International Court of Justice at the request of any one of the parties to the dispute. 
A state party may refer a concern regarding the application of the Convention by another state party, to the International Court of Justice or the UN Security Council to impose sanctions on a breaching state or to persuade a breaching state to amend its resettlement program.

\section{Article 18 - Signature, Ratification and Accession}

This Convention shall be opened for signature at Geneva on 1 January 2020 and shall thereafter be deposited with the Secretary-General of the United Nations. It shall remain open for signature until 31 December 2020.

This Convention shall be open for signature by any Member State of the United Nations, and also by any other state invited to participate by the General Assembly.

Accession or ratification shall be effected by the deposit of an instrument of accession or ratification with the Secretary-General of the United Nations.

\section{Article 19 - Territorial Application Clause}

Any state may, at the time of signature, ratification or accession, declare that this Convention shall extend to all or any of the territories for the international relations of which it is responsible. Such a declaration shall take effect when the Convention enters into force for the state concerned.

At any time thereafter any such extension shall be made by notification addressed to the Secretary-General of the United Nations and shall take effect as from the ninetieth day after the day of receipt by the Secretary-General of the United Nations of this notification, or as from the date of entry into force of the Convention for the state concerned, whichever is the later.

With respect to those territories to which this Convention is not extended at the time of signature, ratification or accession, each state concerned shall extend the application of this Convention to such territories, subject, where necessary for constitutional reasons, to the consent of the governments of such territories.

\section{Article 20 - Reservations}

At the time of signature, ratification or accession, any Contracting State may make reservations to articles of the Convention other than to articles $1-5$ and $8-12$ inclusive. 
Any Contracting State making a reservation in accordance with paragraph 1 of this article may at any time withdraw the reservation by a communication to that effect addressed to the Secretary-General of the United Nations.

\section{Article 21 -Denunciation}

Any Contracting State may denounce this Convention at any time by a notification addressed to the Secretary-General of the United Nations.

Such denunciation shall take effect for the Contracting State concerned one year from the date upon which it is received by the Secretary-General of the United Nations.

Any Contracting State which has made a declaration or notification of extension under article 18 may at any time thereafter, by a notification to the Secretary-General of the United Nations, declare that the Convention shall cease to extend to such territory one year after the date of receipt of the notification by the Secretary-General.

\section{Article 22-Revision}

Any Contracting State may request revision of this Convention at any time by a notification addressed to the Secretary-General of the United Nations.

The General Assembly of the United Nations shall recommend the steps, if any, to be taken in respect of such request.

\section{Article 23 - Notifications by the Secretary-General of the United Nations}

The Secretary-General of the United Nations shall inform all Members of the United Nations and Non-Member States of declarations, notifications, signatures, ratifications, accessions, reservations, withdrawals and requests for revision made in accordance with the articles of this Convention, as well as the date on which this Convention will come into force in accordance with article 20 . 


\section{APPENDIX 2: EXPLANATORY NOTES}

\section{Explanatory Notes to the Convention on Refugee RESETTLEMENT}

\section{Preamble}

This replicates some of the language used in the Convention Relating to the Status of Refugees ('1951 Convention'), and makes specific reference to the 1951 Convention and the Protocol Relating to the Status of Refugees ('1967 Protocol'), in an attempt to draw the three documents together as a 'package'. This is with the intention that the influence and wide acceptance of the 1951 Convention and 1967 Protocol will be brought to bear on this Convention.

The reference to the role of the UNHCR lays the groundwork for the later provisions which grant that organisation the power to set the resettlement quotas and monitor the implementation of the Convention.

\section{Article 1: Definitions}

This article sets out the bodies to which this Convention applies and the meaning of 'resettlement'. The definition of 'family member' is wider than that provided in the domestic legislation of some resettlement countries. This is because refugee families are not always nuclear and may include members of the extended family. This definition is taken from the Commentary on the Additional Protocols to the Geneva Conventions of $1949,{ }^{134}$ and thus has solid support in international law.

\section{Article 2: Non-discrimination}

This is one of the core articles of the Convention, as it addresses one of the major problems with resettlement - the use of discriminatory criteria to pick and choose refugees for resettlement. Support for the principle of nondiscrimination can be found in the many international conventions and agreements on the topic, such as the International Convention on the

\footnotetext{
134 Yves Sandoz, Christophe Swinarski and Bruno Zimmermann (eds), Commentary on the Additional Protocols of 8 June 1977 to the Geneva Conventions of 12 August 1949 (International Committee of the Red Cross, 1 January 1986).
} 
Elimination of All Forms of Racial Discrimination, ${ }^{135}$ the Convention on the Elimination of All Forms of Discrimination against Women ${ }^{136}$ and the Convention on the Rights of Persons with Disabilities. ${ }^{137}$

\section{Article 3: Rights granted apart from this Convention}

This article prevents the Convention from overriding protections set out in the 1951 Convention and 1967 Protocol, as well as those in other international human rights instruments such as the Convention on the Rights of the Child. ${ }^{138}$ This includes the guarantee that resettled refugees will acquire the citizenship of the resettlement country, which is prescribed in article 34 of the 1951 Convention.

\section{Article 4: Refugee involvement in resettlement}

The involvement of refugees in the resettlement process and decision is currently extremely limited. They have no right to resettlement, nor any right to determine in which country they will be resettled. ${ }^{139}$ The UNHCR and major resettlement countries have often highlighted the importance of involving refugees in resettlement decision-making and integration activities. ${ }^{140}$

\section{Article 5: Resettlement quotas}

This is one of the core articles of the Convention. It commits signatories to resettling a portion of the total number of refugees assessed by the UNHCR as being in need of resettlement. The precise method used to calculate the portion is not prescribed so as to allow for this to be negotiated by states and modified over time, depending on the most reliable assessment of resettlement capacity.

\footnotetext{
${ }^{135}$ International Convention on the Elimination of All Forms of Racial Discrimination, opened for signature 21 December 1965, 660 UNTS 195 (entered into force 4 January 1969).

${ }^{136}$ Convention on the Elimination of All Forms of Discrimination against Women, opened for signature 1 March 1980, 1249 UNTS 13 (entered into force 3 September 1981).

137 Convention on the Rights of Persons with Disabilities, opened for signature 30 March 2007) 2515 UNTS 3 (entered into force 3 May 2008).

${ }^{138}$ Convention on the Rights of the Child, opened for signature 20 November 1989, 1577 UNTS 3 (entered into force 2 September 1990).

${ }^{139}$ UNHCR Frequently Asked Questions about Resettlement (n 4).

${ }^{140}$ UNHCR, The Integration of Resettled Refugees (Guidance Booklet, 2013) <https://www. unhcr.org/52a6d85b6.pdf>.
} 
One potential method could be to balance the following for each of the 51 countries rated as having 'very high human development' by the United Nations Development Program:

Human Development Index;

Population;

Land mass; and

Number of persons of concern to the UNHCR currently being hosted.

'Persons of concern' to the UNHCR include refugees, asylum seekers, internally displaced persons, returnees (refugees and IDPs) and stateless persons. ${ }^{141}$ It is recognised that a country hosting a large number of persons of concern has less capacity to provide resettlement to refugees; therefore its quota could be reduced accordingly.

The method used to calculate the portions would need to be agreed upon by states (as would the rest of the declaration text) and this is likely to be the subject of considerable debate. The method I have proposed has the advantage of being less vulnerable to manipulation because it would not be in a country's interest to underestimate its HDI in an attempt to reduce its resettlement quota. ${ }^{142}$

\section{Article 6: Bilateral, multilateral and regional resettlement coordination}

This article provides authority for states parties to pool and redistribute their resettlement quotas in cooperation with each other, and to continue cooperating on a regional basis to strengthen and expand resettlement. Several such agreements already exist or are in development, such as the proposed European Union Resettlement Framework. ${ }^{143}$

The article stipulates that such reallocation should be done in coordination with the UNHCR, both to keep the agency aware of where refugees are being resettled (for example for the purposes of family reunification) and to ensure that refugees are not resettled in a country that does not have the capacity to host them.

\footnotetext{
${ }^{141}$ Population Statistics (n 32).

${ }^{142}$ Schuck (n 1).

${ }^{143}$ Radjenovic (n 106).
} 


\section{Article 7: Resettlement transfers}

Article 7 is designed to ensure that no state party is overburdened by having to resettle more refugees than it can accommodate. It is therefore likely to encourage more states to sign the Convention. Where a country has exhausted its resettlement allocation, a refugee in need of resettlement may be transferred (with that refugee's consent) to another resettlement country. If the refugee does not consent they cannot be forcibly transferred. The resettlement country may be able to reduce its resettlement quota for the following year, in negotiation with the UNHCR. This helps prevent the 'pull' factor - the attraction of asylum seekers to particular resettlement countries.

\section{Article 8: Privacy}

Specific protection for the privacy of refugees is not set out in the 1951 Convention or the 1967 Protocol; therefore it has been included here.

\section{Article 9: No compulsion or cost for resettlement and Article 10: No right to resettlement}

These articles set out some of the core requirements of resettlement: that it be voluntary on the part of the refugee and not a mandatory imposition on the resettlement country.

\section{Article 11: Determination of resettlement need and Article 12: Resettlement decision}

These articles provide a division of responsibilities. The UNHCR is responsible for determining which refugees require resettlement, but the ultimate decision to offer resettlement remains with the resettlement country.

The articles also ensure a mostly non-discriminatory approach to resettlement. The exception to this is the security criterion: the 1951 Convention already allows for the exclusion of a refugee based on security concerns, and this is also permitted under the current Convention.

\section{Article 13: Special Resettlement Cases}

The UNHCR has frequently emphasised the need to expand the number of resettlement places offered for emergency situations. ${ }^{144}$ Resettlement on an emergency basis can be life saving. Settling aside at least $10 \%$ of the

\footnotetext{
${ }^{144}$ UNHCR Projected Global Resettlement Needs 2020 (n 3).
} 
resettlement quota for emergency cases will ensure this highly vulnerable group is resettled.

\section{Article 14: Integration}

Integration has moved from being a post-arrival process undertaken by the resettlement country in cooperation with the resettled refugee to function as a discriminatory criterion for resettlement. This article helps return it to the former position.

\section{Article 15: Cooperation of the National Authorities with the United Nations}

Resettlement reporting already occurs but is sometimes inaccurate or incomplete. ${ }^{145}$ This article formalises the reporting requirements and makes the resettlement process more transparent.

\section{Final Clauses: Articles $16-23$}

These articles outline the methods by which a state can become a party to the Convention, make reservations or denounce the Convention. The language of these articles is based on that used in other conventions, such as the 1951 Convention.

Article 17 includes wording that will enable non-state agents to ratify the Convention where they are invited to do so by the General Assembly. One example is Palestine, which is currently afforded non-member observer status by the General Assembly but has been given the right to become a party to treaties and conventions for which the UN Secretary-General is the depository. ${ }^{146}$

Article 20 sets out that the Convention will come into force only once it has been ratified or acceded to by three states. Ideally, the three states would be those with the longest running, and largest resettlement programs — that is, the United States, Canada and Australia. Without the support of these three states it would be difficult, although not impossible, to implement the Convention.

In recognition of the fact that countries without an existing resettlement program may take some time to establish the necessary processes, article 20

\footnotetext{
${ }^{145}$ For example, many resettlement countries do not provide reasons for rejecting cases for resettlement.

${ }^{146}$ Status of Palestine in the United Nations, UN GAOR, 67 ${ }^{\text {th }}$ sess, Agenda Item 37, UN Doc A/RES/67/19 (4 December 2012).
} 
allows for progressive realisation of the Convention's targets by providing one year between the date of ratification or accession and the date that the Convention will enter into force for that country.

\section{Appeal mechanisms}

Like the 1951 Convention, this Convention does not provide a mechanism by which an individual can appeal against a breach of its provisions, nor does it establish a committee to hear such appeals. Such a mechanism was deliberately omitted as it could open the door to potentially millions of appeals by refugees found not to be eligible for resettlement. Under article 17 one state party can refer a dispute with another state party concerning its application of the Convention to the International Court of Justice or for the UN Security Council. 